\title{
Field survey of foliage-dwelling spiders (Arachnida, Araneae) in Peninsular Malaysia
}

\author{
Survei keanekaragaman laba-laba daun (Arachnida, Araneae) \\ di Semenanjung Malaysia \\ Dzulhelmi Muhammad Nasir ${ }^{1 *}$, Suriyanti $\mathrm{Su}^{2}$, Badiozaman Sulaiman ${ }^{3}$, \\ Madihah Halim ${ }^{4}$, Nur-Syahirah Mamat ${ }^{2}$, Farah Nadiah Rosli ${ }^{2}$, Faszly Rahim ${ }^{5}$ \\ ${ }^{1}$ Institute of Biological Sciences, Faculty of Science, University of Malaya \\ 50603 Kuala Lumpur, Malaysia \\ ${ }^{2}$ Center for Earth Sciences and Environment, Faculty of Science and Technology, \\ Universiti Kebangsaan Malaysia, 43600 Bangi, Selangor, Malaysia \\ ${ }^{3}$ Department of Zoology, Faculty of Resource Science and Technology, Universiti Malaysia Sarawak \\ 94300 Kota Samarahan, Sarawak, Malaysia \\ ${ }^{4}$ Faculty of Agroscience, University College of Agroscience Malaysia \\ Lot 2020, Ayer Pa'abas, 78000 Alor Gjah, Melaka, Malaysia \\ ${ }^{5}$ Islamic Science Institute, Universiti Sains Islam Malaysia \\ 71800 Bandar Baru Nilai, Negeri Sembilan, Malaysia
}

(diterima Agustus 2018, disetujui September 2019)

\begin{abstract}
Diversity of spider groups have received less research attention and there are limited published references for spiders from Peninsular Malaysia. The current survey was conducted to locate and identify foliage-dwelling spiders (Arachnida, Araneae) at five different sites in Peninsular Malaysia. Spider specimens were collected using manual search and sweep-netting between September 2012 and November 2012. A total of 92 morpho-species from 65 genera that belong to 15 families have been successfully recorded and identified. The greatest proportion of specimens captured (40\%) were Foliagerunners (Clubionidae, Miturgidae, Oxyopidae, Pisauridae, Salticidae, Scytodidae, Thomisidae), followed by orb-weavers (Araniedae, Nephilidae, Tetragnathidae, Uloboridae) (36.5\%), space-weavers (Pholcidae, Psechridae Theridiidae) (21.5\%) and ground-dwellers (Sparassidae) (2.0\%). Cluster analysis has revealed that the same habitat types share a more similar diversity composition compared to different habitat types, which indicates that spider assemblage composition was partly co-dependent on vegetation structure. However, no significant difference in spider assemblage composition was found between all the five sites which follows that these diurnal group of spiders are actually adaptable to various habitat types.
\end{abstract}

Key words: Araneae, distribution, diurnal, diversity, guild structure

\begin{abstract}
ABSTRAK
Penelitian mengenai keanekaragaman laba-laba dedaunan masih belum banyak dilakukan di Malaysia. Penelitian ini bertujuan untuk mempelajari keanekaragaman laba-laba dedaunan di Semenanjung Malaysia. Dalam penelitian dilakukan pada 5 lokasi berbeda dengan melakukan koleksi laba-laba secara langsung dan sweep net dari bulan September 2012 hingga November 2012. Sebanyak 92 spesies dari 65 genus dari 15 famili telah berhasil dideteksi dan diidentifikasi. Foliage-runners (Clubionidae, Miturgidae, Oxyopidae, Pisauridae, Salticidae, Scytodidae, Thomisidae) (40,0\%) paling tinggi tertangkap/ditemukan,
\end{abstract}

\footnotetext{
*Penulis korespondensi: Dzulhelmi Muhammad Nasir. Institute of Biological Sciences, Faculty of Science, University of Malaya Kuala Lumpur 50603, Malaysia, Tel: +60 125350664, Email: dzul_3my@yahoo.com
} 
diikuti oleh orb-weavers (Araniedae, Nephilidae, Tetragnathidae, Uloboridae) (36,5\%), spaceweavers (Pholcidae, Psechridae Theridiidae) (21,5\%), dan ground-dwellers (Sparassidae) (2,0\%). Berdasarkan indeks kemiripan menunjukkan bahwa komposisi spesies laba-laba bergantung pada struktur vegetasi. Komposisi laba-laba hampir mirip antara lokasi, yang menunjukkan bahwa kelompok laba-laba diurnal ini dapat beradaptasi dengan berbagai jenis habitat.

Kata kunci: Araneae, distribusi, diurnal, guild structure, keanekaragaman

\section{INTRODUCTION}

Spiders are an abundant and diverse group of invertebrates comprising at least 45,000 species (World Spider Catalog 2015) that occupy a wide array of spatial niches, across which they can be easily collected. Spiders are highly adaptive and therefore among the most successful creatures on earth found in all terrestrial ecosystems (McDonald 2007), except on the ice caps of the Antarctica (Hillyard 2007). Spiders are a wellrecognized predator of invertebrates and small vertebrates in the tropical forest and agriculture ecosystems (Wise 1993). However, spider groups have received less research attention and there are limited published references for spiders from Peninsular Malaysia (Norma-Rashid \& Li 2009). Recent spider checklists of Peninsular Malaysia (Norma-Rashid \& Li 2009; Dzulhelmi et al. 2014) revealed that further study of spiders of the region is critically needed. To date, spider diversity inventories of peninsula Malaysia have been compiled from studies done in the mangroves (Norma-Rashid et al. 2009), botanical gardens (Dzulhelmi \& Norma-Rashid 2014), secondary forests (Noraina 1999) and oil palm plantation areas (Wan-Azizi 2008). These inventories have provided basic information on the spider diversity and distribution in some habitats but other major habitats and agricultural ecosystems in Peninsular Malaysia have been neglected.

In addition, spider distributions in Malaysia's island ecosystems are understudied. Such limitation in data prevents the successful implementation of government management plans to conserve fauna which require complete and up to date spiders inventories (Whitmore et al. 2002). Spiders are crucially important in biodiversity conservation as they are the primary controller of insect crop pest (Bhowmick \& Abrol 2017). Due to lack of comprehensive information on spider diversity, basic taxonomic surveys are needed for habitats not previously studied in Malaysia, to identify species present, as well as to compare the species diversity between habitats (Floren \& Deeleman-Reinhold 2005). The goal is not to simply measure species abundance, but to better understand which types of spiders inhabit particular habitat types in Malaysia (Hore \& Uniyal 2008) as a basic guideline to understand the distribution and ecological needs of spider fauna of this country.

This study attempts to identify factors which may influence distribution of spiders, particularly when assessing why different sites with similar habitat may not necessarily have similar spider diversity (Whitmore et al. 2002). We found that spider species occurrence and distribution were strongly influenced by habitat structure and vegetation parameters (Hore \& Uniyal 2008). The aims of this study were to survey and compare occurrence and distribution of foliage-dwelling spider species between five different sites in Peninsular Malaysia, with a focus on species diversity, composition, and guild structure.

\section{MATERIALS AND METHODS}

\section{Research location}

Spider specimens were collected during expeditions conducted between September 2012 and November 2012 at five different locations in Peninsular Malaysia (Table 1; Fig. 1). Penang National Park and Ulu Gombak Field Study Centre were selected as representative sites of lowland dipterocarp forest while lower montane forests were selected in Penang Hill Nature Reserve and Fraser Hill Nature Reserve. Kuala Pilah rubber plantation area is an agricultural ecosystem and treated as an out-group for comparison. This study assumed that the lowland dipterocarp forest, lower montane forest, and rubber plantation are 
Table 1. Sampling locations in Peninsular Malaysia

\begin{tabular}{|c|c|c|c|}
\hline Localities & Coordinates & Habitat type, sea level & Date of collections \\
\hline Penang National Park & $\begin{array}{l}\text { N 5'26'1616”, E } \\
\text { 100¹7'27.16"' }\end{array}$ & $\begin{array}{l}\text { lowland dipterocarp forest, } \\
250 \text { meter a.s.l }\end{array}$ & 9-11 October 2012 \\
\hline Penang Hill Nature Reserve & $\begin{array}{l}\text { N 5'26'16.16", E } \\
100^{\circ} 17^{\prime} 27.16^{\prime \prime}\end{array}$ & $\begin{array}{l}\text { lower montane forest, } 800 \\
\text { meter a.s.l. }\end{array}$ & 6-8 October 2012 \\
\hline Fraser Hill Nature Reserve & $\begin{array}{l}\text { N 3०43'7.68', E } \\
101^{\circ} 44^{\prime} 25.15^{\prime \prime}\end{array}$ & $\begin{array}{c}\text { lower montane forest, } \\
1000 \text { meter a.s.l. }\end{array}$ & 23-25 September 2012 \\
\hline Ulu Gombak Field Study Centre & $\begin{array}{l}\text { N 3'22'60.1”, E } \\
101^{\circ} 47^{\prime} 20.6^{\prime \prime}\end{array}$ & $\begin{array}{l}\text { lowland dipterocarp forest, } \\
800 \text { meter a.s.l. }\end{array}$ & 13-15 November 2012 \\
\hline Kuala Pilah Rubber Plantation & $\begin{array}{l}\mathrm{N} 2^{\circ} 26^{\prime} 56.27^{\prime \prime}, \mathrm{E} \\
102^{\circ} 11^{\prime} 0.76^{\prime \prime}\end{array}$ & $\begin{array}{l}\text { rubber plantation, } 800 \\
\text { meter a.s.1 }\end{array}$ & 17-19 November 2012 \\
\hline
\end{tabular}

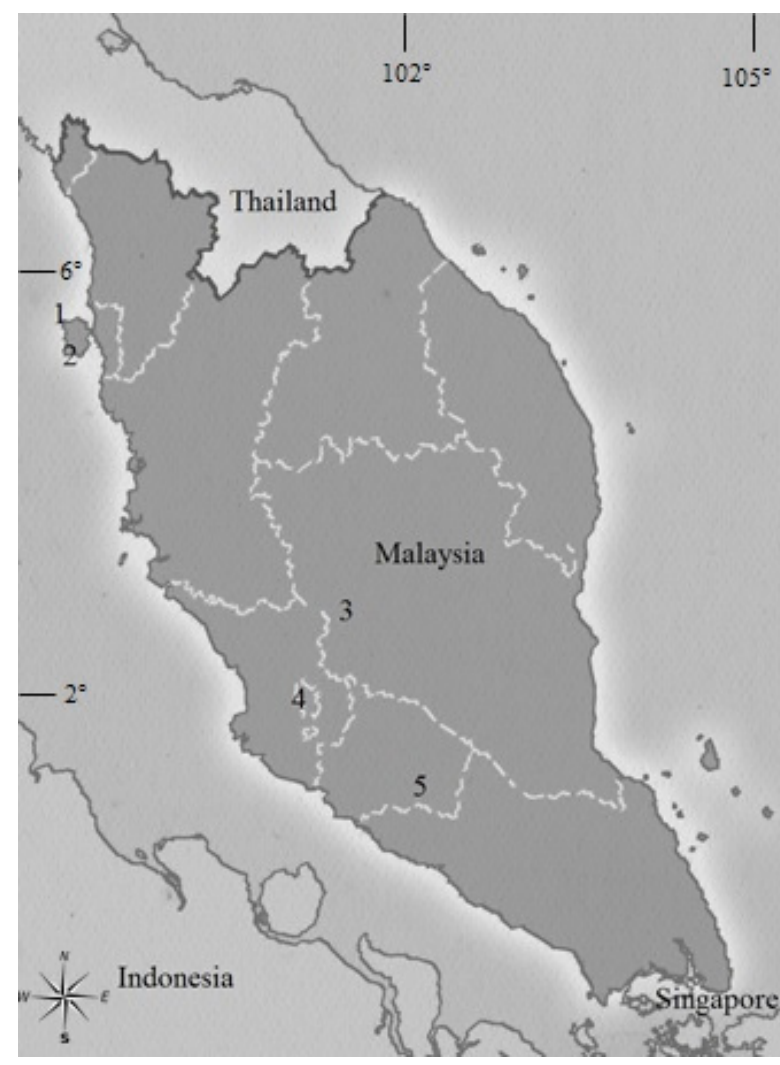

Fig. 1. Map of five sampling sites in Peninsular Malaysia. 1: Penang National Park (Penang); 2: Penang Hill Nature Reserve; 3: Fraser Hill Nature Reserve; 4: Ulu Gombak Field Study Centre; 5: Kuala Pilah rubber plantation area.

characterized by different floral structure with variance diversity and composition attributable to their habitat types and climate condition.

\section{Sampling of spiders}

Field surveys were conducted during the day from 1000 to 1400 hours (four hours total), timed using a stopwatch. Two sampling techniques were applied for three consecutive days at all sites: hand-collecting and sweep-netting. Two people were involved in sampling activity and each person covered $100 \mathrm{~m}^{2}$ per location by using different sampling techniques each as mentioned before. The methods used were standardized for all sampling locations. The net used in sweepnetting technique has a standard anodized aluminium handle which is $119 \mathrm{~cm} \times 19 \mathrm{~mm}$ in diameter, standard hoop which is $380 \mathrm{~mm}$ in diameter, and a white bag which is $74 \mathrm{~cm}$ long. Specimens were stored in $75 \%$ ethanol and brought to the laboratory for species identification. Due to the lack of key from available references for identification of many spider groups, all specimens were classified by morpho-species to the lowest taxa level in laboratory (Hore \& Uniyal 2008). The ideal identification keys for many spider species are considered ambiguous due to complex variation in morphology (Barrett \& Hebert 2005). Species identification was done using Song et al. (1999), Murphy \& Murphy (2000), Sebastian \& Peter (2009), Koh \& Ming (2013), Dzulhelmi \& Suriyanti (2015) as well as visual recognition from experienced research team members.

\section{Data analyses}

Taxonomic diversity, richness, and evenness indices of spider assemblages were calculated using the Shannon and Simpson index, while the composition of spider assemblages found in five localities were tested by Chi-square test using Minitab 17. Between sites similarity of spider fauna was determined using cluster analysis. A useful method for detecting and interpreting potential groupings within items under study (Whitmore et al. 2002). Additionally, spiders were grouped into four major guilds based on hunting strategy and web-building types: 1) orb-weavers (Araniedae, 
Nephilidae, Tetragnathidae, Uloboridae); 2) spaceweavers (Pholcidae, Psechridae, Theridiidae); 3) foliage-runners (Clubionidae, Miturgidae, Oxyopidae, Pisauridae, Salticidae, Scytodidae, Thomisidae); 4) ground-dweller (Sparassidae) (Hore \& Uniyal 2008). ANOVA was done to test for significant differences in taxonomic diversity across habitat types without regard to guild structure. Then, ANOVA comparisons were conducted across habitat sites, within each of the four major guild structure groups respectively. All statistical analyses were performed using the PAST software.

\section{RESULTS}

In this study, approximately 234 individuals, 92 morpho-species belonging to 65 genera and 15 families were recorded during the course of this survey (Table 2). These major families include Araneidae (29\%), Salticidae (21\%), Theridiidae (14\%), Thomisidae (8\%) and Oxyopidae (8\%), Tetragnathidae (4\%) and Pholcidae (4\%), Uloboridae (3\%), Nephiliidae (2\%), Pisauridae (2\%), Clubionidae (1\%), and Psechridae (1\%), Miturgidae (1\%), Scytodidae (1\%) and Sparassidae) (1\%) (Table 3). The Chi-square test revealed significant differences $(p<0.05)$ in spider assemblage composition between the five localities.

Cluster analysis revealed closer distance on spider genera similarity between same habitat types such as Penang National Park with Ulu Gombak Field Study Centre and Fraser Hill Nature Reserve with Penang Hill Nature Reserve, compared to different habitat types (Fig. 2). Meanwhile, Kuala Pilah Rubber Plantation area is an out-group which distinctly differed from all the other locations. However, there was no significant differences in morpho-species composition between all the five sites $(F=0.308, d f=4, P=0.872)$. There was also no significant difference for guild structure between sites $(\mathrm{F}=0.577$, $\mathrm{df}=4, \mathrm{P}=0.679)$. In overall, the capture rates across the sites were almost similar; foliage runners represents $\sim 40 \%$, orb-weavers and space-weavers represent $\sim 36.5 \%$ and $\sim 21.5 \%$ respectively, while ground-dwellers only contribute $\sim 2 \%$ (Fig. 3).

Our results demonstrate that the spider assemblages composition specifically on spider genera are more similar within the same habitat type than across different habitat types, likely because of similar climate conditions (humidity, rainfall, and temperature) and therefore growing conditions for resultant characteristics plant types within specific habitats. The spider species compositions may have been similar between study sites simply because these spiders were the most common diurnal groups of spiders that co-exist in all habitat types. In contrast to the four primary study locations, spider assemblage composition for the out-group location, the Kuala Pilah Rubber Plantation showed greater differences from other sites. This rubber plantation area is a homogeneous vegetation structure dominated by a single tree species with limited under-growth, resulting in different micro-habitats, and therefore different spider species composition compared to other sites.

Table 2. Comparison of spider diversity for each sampling sites

\begin{tabular}{lccccc}
\hline & PHNR & FHNR & PNP & UGFSC & KPRP \\
\hline No of individual & 57 & 49 & 47 & 47 & 34 \\
Simpson & 0.793 & 0.762 & 0.853 & 0.875 & 0.853 \\
Shannon index & 1.797 & 1.757 & 2.085 & 2.296 & 2.049 \\
Evenness & 0.754 & 0.644 & 0.801 & 0.764 & 0.862 \\
Families & 7 & 10 & 9 & 13 & 9 \\
Genera & 25 & 24 & 30 & 33 & 15 \\
Morpho-species & 32 & 30 & 37 & 38 & 16 \\
\hline
\end{tabular}

PHNR: Penang Hill Nature Reserve; FHNR: Fraser Hill Nature Reserve; PNP: Penang National Park; UGFSC: Ulu Gombak Field Study Centre; KPRP: Kuala Pilah Rubber Plantation. 
Table 3. List of spider fauna at five different sites in Peninsular Malaysia. KPRP: Kuala Pilah Rubber Plantation; PNP: Penang National Park; UGFR: Ulu Gombak Field Study Centre; FHNR: Fraser Hill Nature Reserve; PHNR: Penang Hill Nature Reserve

\begin{tabular}{|c|c|c|c|c|c|c|}
\hline Family & Genus & PHNR & FHNR & PNP & UGFSC & KPRP \\
\hline \multirow[t]{14}{*}{ Araneidae } & Araneus & $\sqrt{ }$ & $\sqrt{ }$ & $\sqrt{ }$ & $\sqrt{ }$ & $\sqrt{ }$ \\
\hline & Argiope & $\sqrt{ }$ & $\sqrt{ }$ & $\sqrt{ }$ & $\sqrt{ }$ & $\sqrt{ }$ \\
\hline & Anepsion & $\sqrt{ }$ & & $\sqrt{ }$ & & \\
\hline & Chorizopes & & & $\sqrt{ }$ & & \\
\hline & Cyclosa & $\sqrt{ }$ & $\sqrt{ }$ & & $\sqrt{ }$ & \\
\hline & Cyrtophora & $\sqrt{ }$ & & & & \\
\hline & Gasteracantha & $\sqrt{ }$ & $\sqrt{ }$ & $\sqrt{ }$ & $\sqrt{ }$ & \\
\hline & Singa & & $\sqrt{ }$ & & & \\
\hline & Larinia & & & $\sqrt{ }$ & & \\
\hline & Neoscona & & $\sqrt{ }$ & $\sqrt{ }$ & $\sqrt{ }$ & $\sqrt{ }$ \\
\hline & Paraplectana & & $\sqrt{ }$ & & & \\
\hline & Zygiella & $\sqrt{ }$ & $\sqrt{ }$ & $\sqrt{ }$ & $\sqrt{ }$ & \\
\hline & Araniedae 1 & & & & $\sqrt{ }$ & \\
\hline & Araniedae 2 & & & & $\sqrt{ }$ & \\
\hline Clubionidae & Clubiona & & $\sqrt{ }$ & & & $\sqrt{ }$ \\
\hline Miturgidae & Cheiracanthium & & & $\sqrt{ }$ & & $\sqrt{ }$ \\
\hline \multirow[t]{2}{*}{ Nephiliidae } & Nephila & $\sqrt{ }$ & & & $\sqrt{ }$ & $\sqrt{ }$ \\
\hline & Nephilengys & $\sqrt{ }$ & & & & \\
\hline Oxyopidae & Oxyopes & & & & $\sqrt{ }$ & $\sqrt{ }$ \\
\hline \multirow[t]{4}{*}{ Pholcidae } & Belisana & & & $\sqrt{ }$ & $\sqrt{ }$ & \\
\hline & Pholcus & $\sqrt{ }$ & $\sqrt{ }$ & $\sqrt{ }$ & $\sqrt{ }$ & \\
\hline & Smeringopus & $\sqrt{ }$ & & $\sqrt{ }$ & $\sqrt{ }$ & \\
\hline & Pholcidae 1 & & & & $\sqrt{ }$ & \\
\hline Pisauridae & Eurychoera & & & $\sqrt{ }$ & $\sqrt{ }$ & \\
\hline Psechridae & Fecenia & & $\sqrt{ }$ & & $\sqrt{ }$ & \\
\hline \multirow[t]{5}{*}{ Theridiidae } & Archaeranea & $\sqrt{ }$ & $\sqrt{ }$ & $\sqrt{ }$ & $\sqrt{ }$ & $\sqrt{ }$ \\
\hline & Argyrodes & & & $\sqrt{ }$ & & \\
\hline & Chrysso & & $\sqrt{ }$ & & & \\
\hline & Theridiidae 1 & & & $\sqrt{ }$ & & \\
\hline & Theridiidae 2 & & & $\sqrt{ }$ & & \\
\hline \multirow[t]{4}{*}{ Tetragnathidae } & Leucauge & & $\sqrt{ }$ & $\sqrt{ }$ & $\sqrt{ }$ & \\
\hline & Opadometa & & & & $\sqrt{ }$ & \\
\hline & Tetragnatha & & $\sqrt{ }$ & $\sqrt{ }$ & & \\
\hline & Tylorida & & & & $\sqrt{ }$ & \\
\hline \multirow[t]{9}{*}{ Thomisidae } & Amyciaea & & & & $\sqrt{ }$ & \\
\hline & Angaeus & $\sqrt{ }$ & & & & \\
\hline & Camaricus & & & $\sqrt{ }$ & & \\
\hline & Diaea & & & & $\sqrt{ }$ & $\sqrt{ }$ \\
\hline & Misumenops & $\sqrt{ }$ & $\sqrt{ }$ & & & \\
\hline & Misumena & $\sqrt{ }$ & & & & \\
\hline & Phrynarachne & & & $\sqrt{ }$ & & $\sqrt{ }$ \\
\hline & Strigoplus & & & $\sqrt{ }$ & & \\
\hline & Thomisus & & & & $\sqrt{ }$ & $\sqrt{ }$ \\
\hline Scytodiidae & Scytodes & & & $\sqrt{ }$ & $\sqrt{ }$ & \\
\hline Sparassidae & Pandercetes & & & & $\sqrt{ }$ & $\sqrt{ }$ \\
\hline \multirow[t]{7}{*}{ Salticidae } & Bathippus & & & & $\sqrt{ }$ & \\
\hline & Chrysilla & $\sqrt{ }$ & & $\sqrt{ }$ & $\sqrt{ }$ & \\
\hline & Epeus & $\sqrt{ }$ & & $\sqrt{ }$ & & \\
\hline & Hasarius & & & & & $\sqrt{ }$ \\
\hline & Harmochirus & & & & & $\sqrt{ }$ \\
\hline & Myrmarachne & & $\sqrt{ }$ & & $\sqrt{ }$ & \\
\hline & Omoedus & & & $\sqrt{ }$ & & \\
\hline
\end{tabular}


Table 3. Continued

\begin{tabular}{|c|c|c|c|c|c|c|}
\hline Family & Genus & PHNR & FHNR & PNP & UGFSC & KPRP \\
\hline & Phintella & $\sqrt{ }$ & $\sqrt{ }$ & & & \\
\hline & Plexippus & $\sqrt{ }$ & $\sqrt{ }$ & & $\sqrt{ }$ & $\sqrt{ }$ \\
\hline & Ptocasius & $\sqrt{ }$ & & $\sqrt{ }$ & & \\
\hline & Rhene & $\sqrt{ }$ & & & & \\
\hline & Telamonia & $\sqrt{ }$ & & & $\sqrt{ }$ & \\
\hline & Thiania & $\sqrt{ }$ & $\sqrt{ }$ & & & \\
\hline & Uroballus & & & & $\sqrt{ }$ & \\
\hline & Viciria & $\sqrt{ }$ & $\sqrt{ }$ & $\sqrt{ }$ & & \\
\hline & Salticidae 1 & & $\sqrt{ }$ & & & \\
\hline & Salticidae 2 & & $\sqrt{ }$ & & & \\
\hline & Salticidae 3 & & $\sqrt{ }$ & & & \\
\hline & Salticidae 4 & & & $\sqrt{ }$ & $\sqrt{ }$ & \\
\hline Uloboridae & Uloborus & $\sqrt{ }$ & & $\sqrt{ }$ & $\sqrt{ }$ & \\
\hline
\end{tabular}

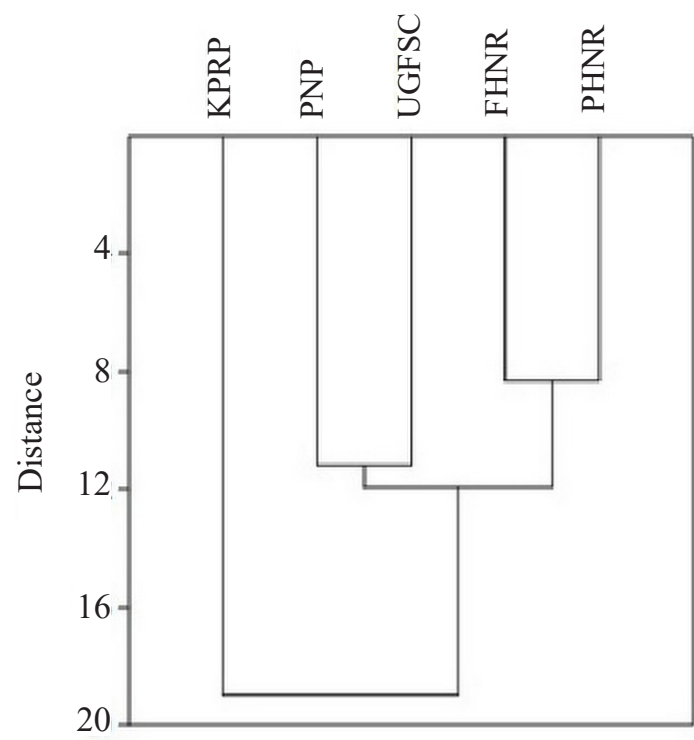

Fig. 2. A dendogram using cluster analysis on spider's genera found in different habitats. KPRP: Kuala Pilah rubber plantation; PNP: Penang National Park; UGFSC: Ulu Gombak Field Study Centre; FHNR: Fraser Hill Nature Reserve; PHNR: Penang Hill Nature Reserve.

\section{DISCUSSION}

Spider fauna abundance and densities depend directly on complex vegetation structure, spatial variability, food abundance, seasonality, competition, predation, environmental stability, and productivity (Wise 1993; Rosenzweig 1995). Studies have demonstrated that a correlation exists between the structural complexity of habitats and the species diversity they contain (Floren \& Deeleman-Reinhold 2005).

Spider diversity generally increases in habitats that are structurally more complex and varied (Green 1999). In addition, high values for Simpson's diversity index may be found in communities with high species richness and a small number of dominant species (Corey \& Taylor 1989). Hence, habitat type is likely to influence the composition of spider assemblages that are clustered together in the same habitat types (Fig. 2). Apart from habitat structure and complexity, other environmental factors (for example, rainfall, humidity, and temperature) may also influence the composition of spider communities, since some species are only adapted to specific environmental conditions (Coddington et al. 1996).

Guild structure constitutes an ecological context of interspecific competition and interactions among spider species (Uetz et al. 1999). The different aspects such as trees height 


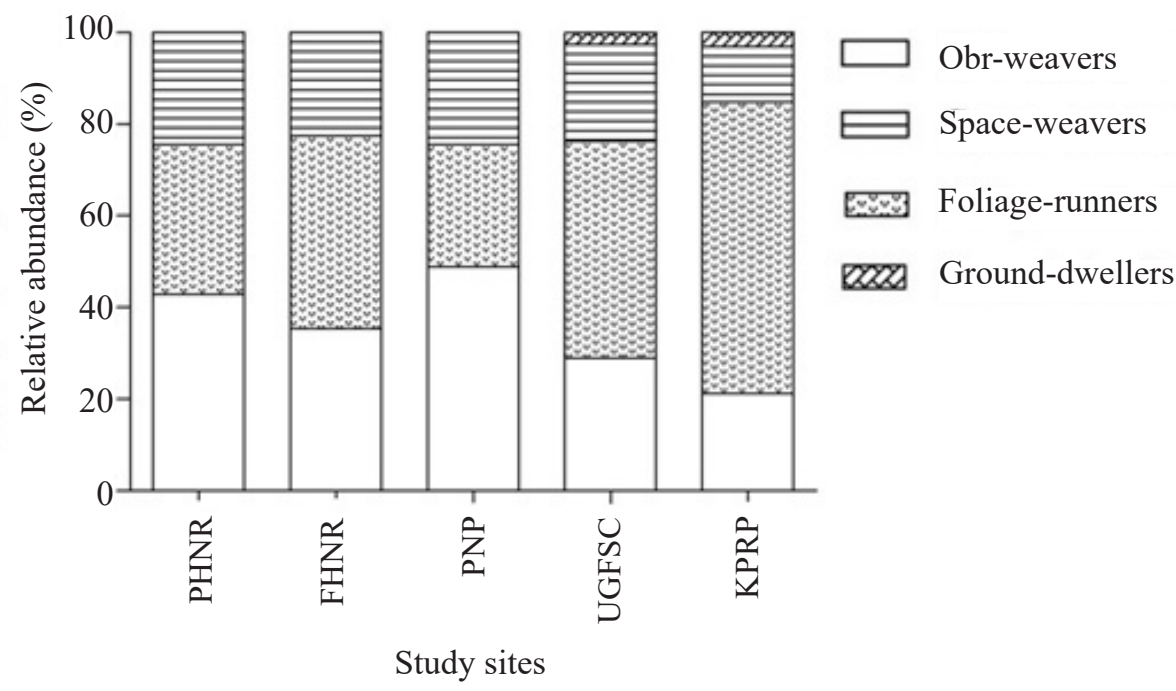

Fig. 3. Guild structure of spiders in five different habitat types. PHNR: Penang Hill Nature Reserve, FHNR: Fraser Hill Nature Reserve, PNP: Penang National Park, UGFSC: Ulu Gombak Field Study Centre and KPRP: Kuala Pilah rubber plantation.

distribution and the kinds of herbaceous vegetation are functionally related to the varying spider guild composition across different habitats (Uetz 1991). In this study, we found no overall significant difference in spider guild compositions between the five sites. Looking specifically at spider composition for different guilds, we would expect to find differences in species composition for foliagedwelling spider assemblages located in habitats of different types and complexity. However, some past studies have also obtained results that show no difference in spider composition between different habitats with different tree structures (Whitmore et al. 2002). Our results indicate that many foliagedwelling spiders seem able to adapt to a variety of habitat types which are characterized by different environmental conditions. This is shown by the presence of many similar spider species recorded at different sites (Table 3).

We examined species composition in the other guilds as well Web-building spiders and foliage-dwelling spiders both highly depend on vegetation structure for some part of their lives, either for finding food, building retreats or building webs (Whitmore et al. 2002). Grounddwellers occupy under-growth shrubs and soil litter (Green 1999) and hide in-between foliage, under leaves or inside self-made silk shelters when not in active mode. Moreover in our study, when the relative abundance of web-weavers was high, the abundance of foliage-runners was lower. This pattern could be an indication of niche partitioning between the two guild structures for spiders.

Web site selection is very crucial for both orbweavers and space-weavers since they construct two-dimensional and three-dimensional webs respectively, and are exposed to various weather conditions (Noraina 1999). Both orb-weavers and space-weavers are highly dependent on substrates for web attachment (Wise 1993). Penang National Park and Penang Hill Nature Reserve had a high abundance of orb-weavers, probably due to suitable micro-habitats in those locations for orb-weavers to construct their webs. The habitat provides high vertical stratification that offer substrates, and open spaces to build webs, with limited exposure to extreme weather. Spaceweavers require similar conditions as web sites, and so we would expect to also find them in high abundance in Penang National Park and Penang Hill Nature Reserve. However abundance of space-weavers was the same across all sites except for in the rubber plantation, where abundance was lower. Compared to orb-weavers, space-weavers can adapt to higher level of disturbance (Tsai et al. 2006) which may explain why they could adapt to all four habitat types. The lower availability of substrate and vegetative structure may explain for the very low abundance of orb-weavers and space weavers in Kuala Pilah rubber plantation area. The habitat does not provide adequate physical structures for web attachment and the 
under-growth shrubs may not be suitable for webweavers and space-weavers to use as substrates for their silk attachment. Other spider guilds were able to succeed in the Kuala Pilah Rubber Plantation, such as foliage runners, who were found in high abundance moving between the plentiful, undergrowths there.

Aside from the comparisons in spider guild compositions among different habitats, the classification based on spider genera were also recorded in our study. The failure to record some genera does not necessarily represent their absence in the habitat, but rather due to their survival behavior, highly cryptic and not sampled adequately (Whitmore et al. 2002) compared to the few genera which are relatively easy to find and capture. The three genera namely Argiope, Araneus (Araneidae), and Archaeranea (Theridiidae) were found at all sites. They are known to adapt and inhabit a wide distribution range from the tropics to temperate region (Koh \& Ming 2013). On the contrary, some genera are only adapted to different climate. For example, the genus Cyrtophora (Araneidae) only occurs in cooler areas (Koh \& Ming 2013; Dzulhelmi \& Suriyanti 2015). Other genera that were not captured in all sites might be low in abundance, since these genera have been reported to occur from various forest types (Norma-Rashid \& Li 2009; Dzulhelmi et al. 2014). Some genera might rest in deep-crevices, respond quickly to threats and rapid escape which make difficulty in capture (Costello \& Daane 2005). The present study showed comparison between diurnal spiders which are almost similar between different habitat types. It is evidence that these spider groups (i.e. genus) can adapt to various habitat types, providing that niche-partitioning takes place between the web-weavers and foliage-runners.

\section{CONCLUSION}

This study identified that the species diversity, composition and guild structure differed between these five different sites. These group of foliagedwelling spider species are adaptable to various habitats types throughout Peninsular Malaysia and co-dependent on vegetation structure.

\section{ACKNOWLEDGEMENTS}

We acknowledge the Department of Wildlife and National Parks (PERHILITAN) for the permission number JPHL\&TN(IP): 80-4/2-Jld-13 to collect samples. Field samplings were funded by the Ministry of Higher Education (MOHE) Fundamental Research Grants Scheme number UKM-ST-06-FRGS0185-2010 awarded to Dr. Faszly Rahim.

\section{REFERENCES}

Barrett RDH, Hebert PDN. 2005. Identifying spiders through DNA barcodes. Canadian Journal of Zoology 83:481-491. doi: https://doi. org/10.1139/z05-024.

Bhowmick A, Abrol DP. 2017. Spiders as natural enemy to control insect pest. In: Abrol DP (Ed.), Technological Innovations in Integrated Pest Management Biorational and Ecological Perspective. pp.225-260. Jodhpur: Scientific Publishers.

Coddington JA, Young LH, Coyle FA. 1996. Estimating spider species richness in a southern Appalachian cove hardwood forest. Journal of Arachnology 24:111-128.

Corey DT, Taylor WK. 1989. Foliage-dwelling spiders in three central Florida plant communities. Journal of Arachnology 17:97-106.

Costello MJ, Daane KM. 2005. Day vs. night sampling for spiders in grape vineyards. Journal of Arachnology 33:25-32. doi: https://doi. org/10.1636/H02-52.

Dzulhelmi M, Norma-Rashid Y. 2014. Spider assemblages in Rimba Ilmu Botanical Garden, Kuala Lumpur, Malaysia. Sains Malaysiana 43:497-502.

Dzulhelmi MN, Suriyanti SNP, Mohamed Z, NormaRashid Y. 2014. New distributional records of spiders (Arachnida: Araneae) from the west coast of peninsular Malaysia. Pakistan Journal of Zoology 46:1573-1584.

Dzulhelmi MN, Suriyanti SNP. 2015. Common Malaysian Spiders. Serdang: University Putra of Malaysia Press.

Floren A, Deeleman-Reinhold C. 2005. Diversity of arboreal spiders in primary and disturbed tropical forests. Journal of Arachnology 33:323-333. doi: https://doi.org/10.1636/05-22.1. 
Green J. 1999. Sampling method and time determines composition of spider collections. Journal of Arachnology 27:176-182.

Hillyard P. 2007. The Private Life of Spiders. London: New Holland Publishers.

Hore U, Uniyal V. 2008. Diversity and composition of spider assemblages in five vegetation types of the Terai Conservation Area, India. Journal of Arachnology 36:251-258. doi: https://doi. org/10.1636/CT07-53.1.

Koh JKH, Ming LT. 2013. Biodiversity in the Heart of Borneo: Spiders of Brunei Darussalam. Borneo: Natural History Publications.

McDonald B. 2007. Effects of vegetation structure on foliage dwelling spider assemblages in native and non-native Oklahoma grassland habitats. Proceedings of the Oklahoma Academy of Science 87:85-88.

Murphy F, Murphy J. 2000. An Introduction to the Spiders of South East Asia. Kuala Lumpur: Malaysian Nature Society.

Noraina M. 1999. Diversiti, Kelakuan dan AspekAspek Berkaitan Sarang dalam Labah-Labah. BSc. Final Year Project. Kuala Lumpur: Universiti Malaya (unpublished).

Norma-Rashid Y, Li D. 2009. A checklist of spiders (Arachnida: Araneae) from Peninsular Malaysia inclusive of twenty new records. The Raffles Bulletin of Zoology 57:305-322. doi: https://doi. org/10.3923/ijzr.2009.9.15.

Norma-Rashid Y, Rahman N, Li D. 2009. Mangrove spiders (Araneae) of peninsular Malaysia. International Journal of Zoological Research 5:9-15.

Rosenzweig ML. 1995. Species Diversity in Space and Time. Cambridge: Cambridge University Press. doi: https://doi.org/10.1017/ CBO9780511623387.
Song DX, Mingsheng Z, Jun C. 1999. The Spiders of China. Shijiazhuang: Hebei Science and Technology Publishing House.

Sebastian P, Peter K. 2009. Spiders of India. Hydrebad: Universities press.

Tsai ZI, Huang PS, Tso IM. 2006. Habitat management by aboriginals promotes high spider diversity on an Asian tropical island. Ecography 29:8494. doi: https://doi.org/10.1111/j.2006.09067590.04425.x.

Uetz GW, Halaj J, Cady AB. 1999. Guild structure of spiders in major crops. Journal of Arachnology 270-280.

Uetz G. 1991. Habitat structure and spider foraging. Habitat structure 8:325-348. doi: https://doi. org/10.1007/978-94-011-3076-9_16.

Wan Azizi W. 2008. The Diversity and Behavioural Ecology of Webbing Spiders in Carey Island. Undergraduate Thesis. Kuala Lumpur: University Malaya.

Whitmore C, Slotow R, Crouch TE, DippenaarSchoeman AS. 2002. Diversity of spiders (Araneae) in a savanna reserve, Northern Province, South Africa. Journal of Arachnology 30:344-356. doi: https://doi.org/10.1636/01618202(2002)030[0344:DOSAIA]2.0.CO;2.

Wise DH. 1993. Spiders in Ecological Webs. United Kingdom: Cambridge University Press. doi: https://doi.org/10.1017/CBO9780511623431.

World Spider Catalog. 2015. World spider catalog. Available at: http://wsc.nmbe.ch, version 16.5 [accessed 5 June 2015]. 